that tradition" and he noted that above all else, Jim Burns had rejected pragmatism, complacency, and moral evasion as he searched for more effective ways to encourage moral leadership and effective governance for our political system.

Historian Michael R. Beschloss, a former student of Burns' at Williams, observed that "As President of the American Political Science Association and the International Society for Political Psychology, he has brought meaning to the word colleague and has been notably generous to younger scholars. Teaching political science for four decades at his beloved Williams College, it might be said, he has never treated a student simply as a student." Beschloss added: "Recitation of Jim's careers as scholar, activist, academic leader, and teacher does nothing to convey his decency, curiosity, zeal, iconoclasm, and steadfastness to principle. This volume of essays by twelve of his friends and colleagues is to honor him on his seventieth birthday. . . . All of the essays reflect our pleasure to know him and our satisfaction in his singular place in American scholarship, letters, teaching, and politics."

\section{Bourgin Attends Annual Meeting}

Frank P. Bourgin was among the over 4,000 political scientists who attended the Washington Annual Meeting. Bourgin received national attention when after 43 years the University of Chicago's Department of Political Science reversed itself by accepting his doctoral thesis and awarded Bourgin his Ph.D. at the age of 77.

Bourgin's dissertation argues that the New Deal was firmly rooted in the activist federal government envisioned by the framers of the U.S. Constitution. In 1945 when Bourgin submitted his dissertation for approval it was universally held that the framers of the Constitution had envisioned a laissez-faire government. The Chicago Department rejected Bourgin's thesis, and Bourgin left the University without realizing his goal of securing a Ph.D.

Bourgin's academic career took a sudden turn for the better when historian Arthur Schlesinger, to whom Bourgin had. sent a synopsis of his rejected dissertation, encouraged Chicago's department to reconsider Bourgin's work. Bourgin's dissertation was accepted and is scheduled for publication later this year.

This year Bourgin was named an honorary Life Member of APSA.

\section{Foreign Students Attend 1988 APSA and IPSA Meetings with Grant Support}

Through funds provided by the Institute for International Education, The Asia Foundation, and the German Marshall Fund of the United States, 60 foreign graduate students studying political science in the United States were given grants to help pay for their travel expenses to the IPSA 14th World Congress and the 1988 APSA Annual Meeting. Of the 61 awards, 24 were funded by the Institute for International Education; 35 by the Asia Foundation; and 2 by the German Marshall Fund.

Students from 23 countries were among the grantees. The country distribution of the awards included: Burma (1), Republic of China (6), People's Republic of China (8), Korea (14), Japan (2), Bangladesh (2), Pakistan (1), Sri Lanka (1), West Germany (3), Canada (3), Nigeria (2), Ethiopia (1), Cameroons (I), Norway (1), Italy (1), Jordan (1), United Kingdom (3), India (4), Argentina (I), El Salvador (1), Nicaragua (I), Iran (I), and Mexico (2).

Listed below are the recipients with their country of origin and current institution.

\section{IIE Travel Grantees}

Konrad Stenzel, West Germany; Yale University

Geoffry B. Robinson, Canada; Cornell University 